\title{
Predation by Aequorea victoria on other species of potentially competing pelagic hydrozoans
}

\author{
Jennifer E. Purcell \\ Horn Point Environmental Laboratories, PO Box 775, Cambridge, Maryland 21613, USA
}

\begin{abstract}
The hydromedusa Aequorea victoria included 10 gelatinous species in its diet, comprising $10.5 \%$ of the total number of prey items. I address the effects of this intraguild predation on densities of prey medusae and zooplankton, and assess the probability of competition for food among gelatinous species. A. victoria may limit the population sizes of its gelatinous prey species, as indicated by inverse correlation of predator and prey densities. The zooplankton diet of $A$. victoria substantially overlapped the diets of its gelatinous prey species, demonstrating a potential for competition. Zooplankton densities were inversely correlated with gelatinous predator densities, and their predation may limit zooplankton densities at times. Therefore, competition for food sometimes may occur between gelatinous species. For this and other reasons, intraguild predation appears to be advantageous for medusae.
\end{abstract}

\section{INTRODUCTION}

Intraguild predation is defined as the eating of species that use similar, often limiting, resources and are thus potential competitors' (Polis et al. 1989). The predators may gain energetic advantages both from the intraguild prey and from reduced competition for food. Intraguild predation occurs widely among taxonomically unrelated arthropods and vertebrates in terrestrial, freshwater, and marine environments (reviewed in Polis et al. 1989). Intraguild predation also commonly occurs among taxonomically similar species of predators, which often have very similar resource requirements. Examples of this in marine plankton are among chaetognaths (Pearre 1982b), copepods (Hodgkin \& Rippingale 1971), ctenophores (Greve 1977), and cnidarians (reviewed in Purcell 1991). Intraguild predation is common by species of hydromedusae and scyphomedusae, but less common by other gelatinous predators (Purcell 1991)

Population level effects of intraguild predation are very complex (Polis et al. 1989). In gelatinous zooplankton, this was addressed by 2 previous studies. Increased copepod populations and reduced phytoplankton followed predation by the scyphomedusa Chrysaora quinquecirrha on the ctenophore Mnemiopsis leidyi (Feigenbaum \& Kelly 1984). The effects of predation by adult ctenophores Pleurobrachia pileus on copepods Calanus helgolandicus and predation by $C$. helgolandicus on larval $P$, pileus were modelled by Greve (1977).

Most intraguild predation occurs by generalist predators that are large compared with their intraguild prey (Polis et al. 1989). This is true among pelagic cnidarians and ctenophores (Purcell 1991). Aequorea victoria is a large hydromedusan $(60 \mathrm{~mm}$ in diameter) that eats other smaller gelatinous zooplanktivores as well as a variety of zooplankton (Purcell 1989).

The potential for dietary competition among gelatinous predators and prey has not been evaluated previously. Because the diets and predation impacts of hydromedusae in the Northeast Pacific recently have been quantified (Larson 1985, Purcell 1989, 1990) the opportunity arose to examine intraguild predation by the hydromedusa Aequorea victoria, the degree of dietary overlap between $A$. victoria and its gelatinous prey species, and the possibility of food limitation and competition for food among gelatinous species.

\section{MATERIALS AND METHODS}

All gelatinous species and other zooplankton taxa were counted and identified from samples taken with a $0.75 \mathrm{~m}$ diameter, $333 \mu \mathrm{m}$ plankton net with a flowmeter towed at 1 and $5 \mathrm{~m}$ depths at 2 stations and at $1 \mathrm{~m}$ depth at 1 station in Kulleet Bay, Vancouver Island, British Columbia, Canada, on 11 dates at weekly inter- 
vals in March through May, 1983. Details of the sampling protocol and sample analysis are in Purcell (1989). Comparable samples were taken in Kulleet Bay on April 9 to 11, 1984, April 14 to 21, 1985, March 31. 1986, and March 31 to April 2, 1987. Sample sets were collected in both the day and night on several dates. Weather conditions sometimes prevented collection of all 10 tows on each date. In total, data from 354 tows are included here. Paired comparisons showed that differences between hydromedusa densities in duplicate tows were not statistically significant (Wilcoxon Signed Ranks test, $\mathrm{p}=0.33$ ).

Prey organisms were counted and identified from the gut contents of Aequorea victoria collected individually by dip net from the surface $1.5 \mathrm{~m}$ of Kulleet Bay and immediately preserved in $5 \%$ formalin. One gut content sample containing several $A$. victoria was collected at each station at each sampling time in 1983 to 1987. The gut contents of 801 medusae (104 samples) were examined over 5 yr. Partially digested gelatinous prey were identified by the species-specific shape of the swimming bell and arrangements of gonads and tentacles. Analysis of other dietary components is in Purcell (1989).

Analysis of prey selection by Aequorea victoria for gelatinous species was done on 424 medusae collected in 1983 only, due to the low numbers of gelatinous prey in other years. Results were pooled from March through May 1983, because the numbers of gelatinous prey were too small to test by station or by date. The various gelatinous species were present in similar proportions throughout the sampling period (Purcell 1989) so pooling the data should not bias the results. For this analysis (Pearre 1982a), I used the total number of each prey species in the gut contents of $A$. victoria and the mean densities (number $\mathrm{m}^{-3}$ ) of each species in situ.

Regression analyses were done on log-transformed data from each station (mean densities of Aequorea victoria, other medusae, siphonophores, total softbodied species, and zooplankton, and the numbers of medusae and siphonophores eaten by A. victoria). The numbers in each regression are not equal because $A$. victoria sometimes could not be collected for gut analysis, and because logarithmic transformation of the data eliminated data equal to zero

The degrees of dietary overlap between Aequorea victoria and its gelatinous prey species in Kulleet Bay were calculated using the method of Kohn \& Riggs (1982) from data on zooplankton eaten by these species. The numbers of prey eaten $\mathrm{m}^{-3} \mathrm{~d}^{-1}$ by gelatinous species were estimated from the number of prey medusa-1 (Purcell 1990) divided by $4 \mathrm{~h}$ digestion time (Plotnikova 1961, Larson 1985), multiplied by the mean densities of each species on every date (Purcell 1989). The assumption of continuous feeding over $24 \mathrm{~h}$ is supported by day and nighttime collections of gelatinous predators in this region (Purcell 1982, 1989, Purcell \& Mills 1988).

\section{RESULTS}

Aequorea victoria medusae examined throughout spring 1983 contained 697 hydromedusae, 861 polygastric and eudoxid siphonophores, and 16 ctenophores. Gelatinous prey represented $10.5 \%$ of the 15033 prey items found in the gut contents. Zooplankton prey items included copepods and nauplii, cladocerans, barnacle nauplii, crab zoeas, shrimp larvae, euphausiid eggs and nauplii, larvaceans, tintinnids, and fish larvae.

The numbers of hydromedusae eaten per Aequorea victoria medusa increased significantly with increasing densities of the prey species $(p<0.01$; Fig. 1). The

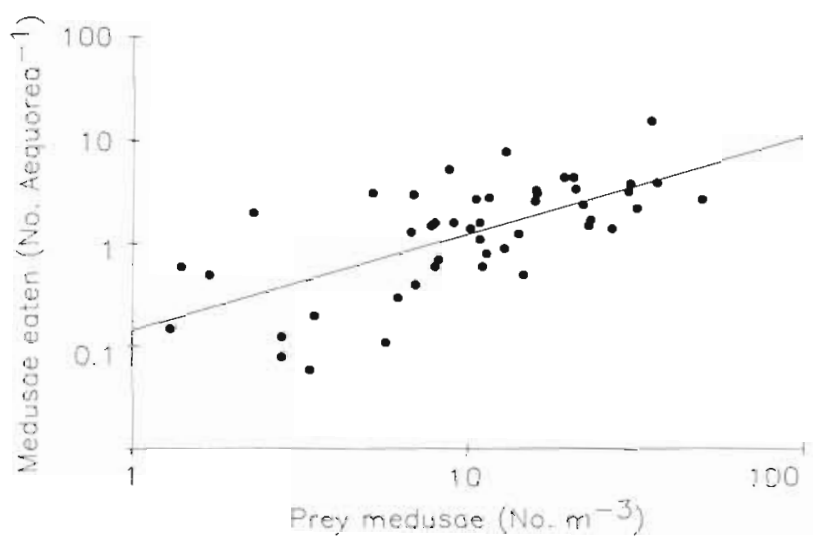

Fig. 1. Numbers of hydromedusae eaten by Aequorea victoria increased with increasing densities of prey species in situ. Regression: $y=0.15 x^{092} ; r=0.66 ; n=47$ stations

numbers of siphonophores eaten were also significantly correlated with their densities in situ $(n=36$ stations, $r=0.34, p<0.05$ ). During March through May, 1983, densities of prey hydromedusa species increased from $3.2 \pm 2.8 \mathrm{~m}^{-3}$ to $22.5 \pm 17.5 \mathrm{~m}^{-3}$, and siphonophores increased from $2.4 \pm 3.8$ to $24.4 \pm 18.3$ $\mathrm{m}^{-3}$. During the shorter sampling periods in subsequent years, medusa densities averaged $6.9 \pm 3.4 \mathrm{~m}^{-3}$ in $1984,2.5 \pm 1.0 \mathrm{~m}^{-3}$ in $1985,12.2 \pm 13.5 \mathrm{~m}^{2}$ in 1986 , and $2.5 \pm 1.6 \mathrm{~m}^{-3}$ in 1987. Siphonophore densities were less than $1 \mathrm{~m}^{-3}$ except in 1986, when they averaged $4.1 \pm 3.0 \mathrm{~m}^{-3}$.

The numbers of other gelatinous zooplankton may be limited at high densities of Aequorea victoria. Mean densities of $A$. victoria differed by as much as 1000 -fold between years, from less than $0.005 \mathrm{~m}^{-3}$ in 1983,1986 and 1987 to $5.1 \mathrm{~m}^{-3}$ in 1985. Densities of $A$. victoria were inversely correlated with densities of other medusae $(p<0.01$, Fig. 2). In contrast, A. victoria 


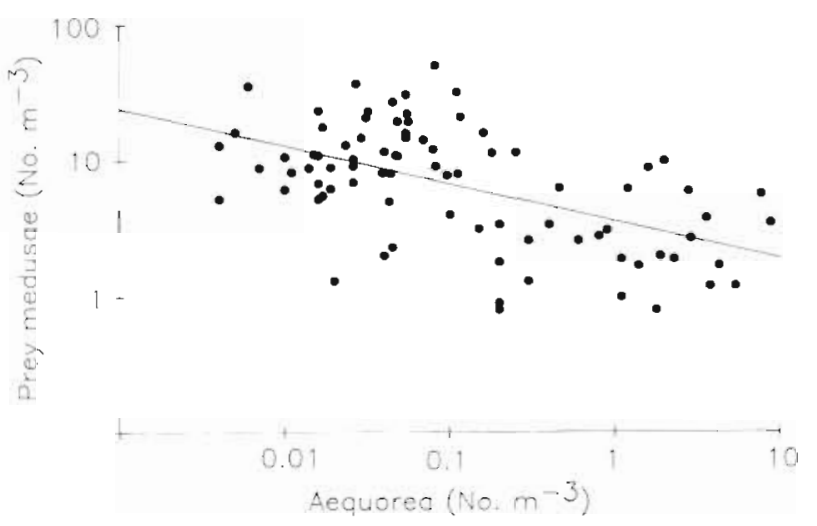

Fig. 2. Densities of prey hydromedusae were inversely correlated with densities of $A$. victoria in situ. Regression: $y=$ $3.58 x^{-0.275} ; \mathrm{r}=-0.55 ; \mathrm{n}=82$ stations

densities were positively correlated with zooplankton densities ( $\mathrm{n}=82$ stations, $\mathrm{r}=0.41, \mathrm{p}<0.01$ ).

Several hydromedusa species, 2 siphonophore species (mostly Muggiaed atlantica, and some Dimophyes arctica), and one ctenophore species (Pleurobrachia bachei) were eaten by Aequorea victoria (Table 1). Selection for gelatinous prey by $A$. victoria was shown to be positive while selection for crustacean prey was negative (Purcell 1989). However, selection by $A$. victoria for individual gelatinous species was not significantly different from zero, except for Aglantha digitale and Proboscidactyla flavicirrata which were eaten less than expected given their densities in the environment (Chi-square $=30.0$ and 53.2 , respectively; degrees of freedom $=1 ; p<0.001$; Table 1 ).

The diets of Aequorea victoria and their gelatinous prey showed substantial overlaps; the index of dietary overlap ranged from 0.07 to $0.73,1.0$ being complete overlap (Table 2). The overlap index was low $(\leq 0.10)$ for species (Eutonina indicans, Obelia sp., Aglantha digitale and Proboscidactyla flavicirrata) that ate mostly tintinnids or invertebrate eggs. The overlap index was slightly higher $(0.10$ to 0.16$)$ for species (Pleurobrachia bachei, Sarsia tubulosa, Muggiaea atlantica), that ate mostly crustacean zooplankton. The greatest overlaps (0.43 to 0.73$)$ were with diets of species (Rathkea octopunctata, Phialidium gregarium, Mitrocomella polydiademata) that had high percentages of soft-bodied prey.

In order to determine if predation by gelatinous species could limit zooplankton populations, I estimated the numbers of zooplankton eaten by all species combined in Kulleet Bay in 1983 (Table 3). Predation in March was low $\left(<4 \%\right.$ of the standing stock $\mathrm{d}^{-1}$ ), but in April, predation had increased to between 18 and $37 \%$ $\mathrm{d}^{-1}$. Densities of zooplankton and gelatinous species other than Aequorea victoria were inversely correlated (Fig. 3; p < 0.01), which also suggests that predation may limit zooplankton populations.

\section{DISCUSSION}

Densities of Aequorea victoria were negatively correlated with densities of their gelatinous prey. Inversely correlated densities also have been reported for the scyphomedusa Chrysara quinquecirrha and the ctenophore Mnemiopsis leidyi in Chesapeake Bay (Feigenbaum \& Kelly 1984 and references therein), and were interpreted as predator control of ctenophore populations. Correlations cannot indicate cause and effect, therefore predation is only one of the possible reasons for negative correlations. Alternatively, gelatinous populations could have been limited by low zooplankton prey densities. However, in the present study, the opposite pattern was seen; densities of

Table 1. Numbers of gelatinous zooplankton from the gut contents of 424 Aequorea victoria, their densities (no. $\mathrm{m}^{-3}$ ) in the environment, and the indices of selection of these prey

\begin{tabular}{|c|c|c|c|}
\hline Prey species & No. eaten & $\begin{array}{l}\text { Density in } \\
\text { environment }\end{array}$ & $\begin{array}{l}\text { Pearre's (1982a) } \\
\text { index of selection }\end{array}$ \\
\hline Muggiaea atlantica & 861 & 11.0 & 0.032 \\
\hline Rathkea octopunctatá & 258 & 5.0 & 0.0003 \\
\hline Eutonina indicans & 190 & 0.8 & 0.030 \\
\hline Phialidium gregarium & 163 & 1.3 & 0.015 \\
\hline Unidentified leptomedusae & 38 & 0.5 & - \\
\hline Obelia sp. & 23 & 1.8 & 0.033 \\
\hline Pleurobrachia bachei & 16 & 1.6 & 0.042 \\
\hline Sarsia tubulosa & 11 & 1.0 & 0.014 \\
\hline Miscellaneous anthomedusae & 6 & 0.3 & - \\
\hline Mitrocomella polydiademata & 4 & 0.2 & -0.028 \\
\hline Proboscidactyla flavicirrata & 3 & 1.5 & $-0.182 \cdots$ \\
\hline Aglantha digitale & 1 & 1.6 & $-0.137 \cdots$ \\
\hline
\end{tabular}


Table 2. Percentages of prey items in the diets of Aequorea victoria and their gelatinous prey species, index of dietary overlap between $A$. victoria and each other species, and estimated number of prey consumed daily by each predator

\begin{tabular}{|c|c|c|c|c|c|c|c|}
\hline Species & $\begin{array}{l}\text { Invertebrate } \\
\text { eggs and } \\
\text { tintinnids }\end{array}$ & $\begin{array}{l}\text { Mero- } \\
\text { plankton }\end{array}$ & Copepods & Larvaceans & Other ${ }^{a}$ & $\begin{array}{l}\text { Index of } \\
\text { dietary } \\
\text { overlap }\end{array}$ & $\begin{array}{l}\text { No. of } \\
\text { prey } \mathrm{d}^{-1} \\
\text { predator }\end{array}$ \\
\hline A. victoria & + & 5.9 & 9.5 & 68.0 & 16.6 & - & 276.5 \\
\hline M. atlantica ${ }^{b}$ & 0 & 0 & 100 & 0 & 0 & 0.10 & 8.0 \\
\hline R. octopunctata ${ }^{C}$ & 0 & 62.5 & 0 & 25.0 & 12.5 & 0.43 & 0.1 \\
\hline E. indicans ${ }^{\circ}$ & 89.5 & 2.1 & 2.8 & 3.2 & 2.3 & 0.10 & 135.0 \\
\hline P. gregarium ${ }^{c}$ & 54.6 & 0 & 1.8 & 36.4 & 1.8 & 0.45 & 13.8 \\
\hline Obelia sp. & 100 & 0 & 0 & 0 & 0 & 0 & 0.03 \\
\hline P. bachei & 0 & 5.2 & 92.2 & 2.6 & 0 & 0.17 & 4.8 \\
\hline S. tubulosa $a^{c}$ & 0 & 83.9 & 15.5 & 0 & 0.3 & 0.16 & 83.1 \\
\hline$M$ polydiademata ${ }^{c}$ & 0 & 2.3 & 2.3 & 95.4 & 0 & 0.73 & 58.7 \\
\hline P. flavicirratac & 70.3 & 28.7 & 0 & 0 & 1.0 & 0.07 & 11.4 \\
\hline A digitaler & 80.0 & 0 & 20.0 & 0 & 0 & 0.09 & 0.6 \\
\hline \multicolumn{8}{|c|}{$\begin{array}{l}\text { a Mostly gelatinous zooplankton and fish larvae } \\
\text { bata from Purcell (1982) } \\
\text { c Data modified from Purcell \& Mills (1988) } \\
+ \text { : present }\end{array}$} \\
\hline
\end{tabular}

Table 3. Densities (mean no. $\mathrm{m}^{-3} \pm 1 \mathrm{SD}$ ) of gelatinous zooplanktivores and zooplankton in Kulleet Bay in 1983. Percentages of zooplankton consumed per day were calculated from the no. eaten $\mathrm{m}^{-3} \mathrm{~d}^{-1} \div$ (no. eaten $\mathrm{m}^{-3} \mathrm{~d}^{-1}+$ mean no. $\mathrm{m}^{-3}$ )

\begin{tabular}{|c|c|c|c|c|c|}
\hline Date & & $\begin{array}{c}\text { Soft-bodied predators } \\
\text { (no. } \mathrm{m}^{-3} \text { ) }\end{array}$ & $\begin{array}{l}\text { Prey eaten } \\
\left.\text { (no. } \mathrm{m}^{-3} \mathrm{~d}^{-1}\right)\end{array}$ & $\begin{array}{c}\text { Zooplankton } \\
\left(\text { no. } \mathrm{m}^{-3}\right)\end{array}$ & $\begin{array}{c}\text { Consumed } \\
\left(\% \mathrm{~d}^{-1}\right)\end{array}$ \\
\hline \multirow[t]{4}{*}{ March } & 9 & $1.8 \pm 0.6$ & 45.6 & $2476 \pm 782$ & 1.8 \\
\hline & 15 & $3.7 \pm 2.2$ & 68.5 & $5164 \pm 5346$ & 1.3 \\
\hline & 22 & $7.8 \pm 4.0$ & 108.1 & $6876 \pm 3629$ & 1.6 \\
\hline & 29 & $17.7 \pm 9.7$ & 192.4 & $5110 \pm 3427$ & 3.6 \\
\hline \multirow[t]{4}{*}{ April } & 5 & $22.6 \pm 20.3$ & 529.8 & $24.15 \pm 1216$ & 18.0 \\
\hline & 13 & $14.2 \pm 11.1$ & 629.1 & $1067 \pm 216$ & 37.1 \\
\hline & 19 & $19.1 \pm 8.0$ & 400.3 & $2301 \pm 677$ & 14.8 \\
\hline & 26 & $14.2 \pm 8.2$ & 290.6 & $4989 \pm 3610$ & 5.5 \\
\hline \multirow[t]{3}{*}{ May } & 2 & $26.0 \pm 18.4$ & 804.9 & $4884 \pm 2194$ & 14.2 \\
\hline & 9 & $35.1 \pm 16.0$ & 383.8 & $3888 \pm 1395$ & 9.0 \\
\hline & 21 & $45.7 \pm 25.4$ & 410.0 & $1598 \pm 272$ & 20.1 \\
\hline
\end{tabular}

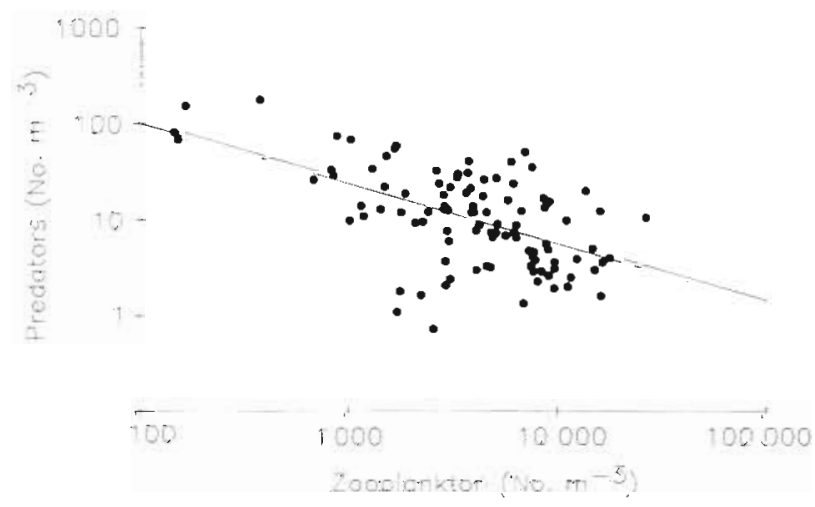

Fig. 3. Densities of zooplankton and soft-bodied zooplanktivores, excluding Aequorea victoria, were inversely correlated in situ. Regression: $y=3742 x^{-0.733} ; \mathrm{r}=-0.57 ; \mathrm{n}=103$ stations gelatinous species other than $A$. victoria were low at high zooplankton densities. Therefore, predation by $A$. victoria was more likely than food limitation to be the cause of the negative correlation between densities of A. victoria and other gelatinous species.

Gut content data are affected by the times required to digest various prey. The proportions of quickly digested prey would be low relative to slowly digested prey. Because digestion rate data are lacking for most species, I made the following assumptions. For analysis of selection of gelatinous prey species by Aequorea victoria, I assumed that all gelatinous species were digested at similar rates. Data are available only for Pleurobrachia bachei 9 to $10 \mathrm{~cm}$ in diameter, which $A$. victoria digested in $3.8 \pm 0.6 \mathrm{~h}$ at $18^{\circ} \mathrm{C}$ (M. N. Arai pers. comm.). This is similar to the time $A$. victoria 
requires to digest herring larvae at $10^{\circ} \mathrm{C}$ (Purcell 1989). Temperatures in Kulleet Bay were 8 to $11^{\circ} \mathrm{C}$ during March to June, 1983 , and 9 to $10^{\circ} \mathrm{C}$ in April of other years. I assumed that no significant differences in digestion rates occurred over that temperature range. For analysis of dietary overlap between predator and prey species, I assumed that digestion times for the various zooplankters differed consistently among predator species. For example, copepod nauplii would be digested more rapidly than copepodites by all predators

Although selection for gelatinous prey was generally positive, Aequorea victoria strongly selected against 2 species, Proboscidactyla flavicirrata and Aglantha digitale. One explanation for this is that both species exhibit escape responses. A. digitale exhibits a strong swimming burst for escape (Donaldson et al. 1980) and $p$. flavicirrata has a defensive 'crumpling response' (Spencer 1975). Other reports of behaviors that reduce predation on medusae are rare. Stomotoca atra stops swimming in the presence of A. victoria, possibly reducing their encounters (Lenhoff 1964). Among scyphomedusae, Aurelia aurita showed 3 types of responses to contact with Phacellophora camtschatica, and $95.8 \%$ of the medusae escaped (Strand \& Hamner 1988)

Intraguild predation can involve any of the life history stages of the interacting species (Polis et al. 1989). Herein, I examined predation among the medusa stage of hydrozoans. Pennington (1990) found that Phialidium gregarium ate embryonic and larval Aequorea victoria, but that $A$. victoria, which eats few small prey, ate few early stage $P$. gregarium. Such ontogenetic reversals of the predation hierarchy may promote diversity and stability among these predator populations

The effects of intraguild among gelatinous zooplankton in Kulleet Bay are summarized in Fig. 4. At high densities, predation by Aequorea victoria can limit populations of other gelatinous zooplanktivores. High

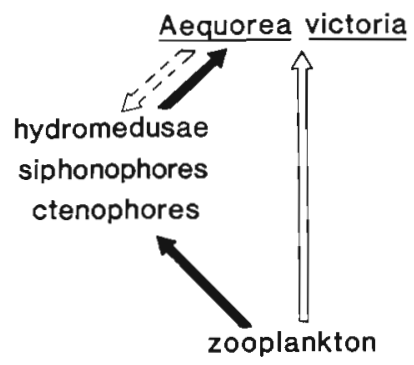

Fig. 4. Predation among gelatinous zooplanktivores in Kulleet Bay. Solid arrows indicate that predation by one level (head of arrow) may limit the populations of another (base of arrow). Open arrows indicate that the populations probably were not limited by the predation. Dashed arrow indicates consumption of larvae (Pennington 1990) densities of zooplanktivores can reduce zooplankton populations. Therefore, intraguild predation by $A$. victoria could reduce predation on zooplankton.

Intraguild predation seems to be obviously advantageous for medusae, with few apparent disadvantages. Aequorea victoria has a diverse diet of zooplankton that includes gelatinous zooplankton. Such prey may seem to be of little food value, however a medusa $1 \mathrm{~cm}$ in diameter contains about $500 \mu \mathrm{g}$ carbon, compared with 4 to $50 \mu \mathrm{g}$ carbon in various smaller zooplankton taxa (Larson 1985). The large size of gelatinous zooplankton also increases the chance of encounter with a tentaculate predator. They also may be easy to catch because they lack an exoskeleton, and their thin, external tissue may be easy to digest. Possible reduction of competition for zooplankton prey is an additional benefit that results from eating other zooplanktivores.

The disadvantages of intraguild predation may be the unknown costs of capturing stinging prey, and reduced feeding while handling large intraguild prey. The large size of intraguild predators may make them less efficient than their intraguild prey at feeding on small foods (Polis et al. 1989). While Aequorea victoria eats few microzooplankton, its abundant, large zooplankton prey have high carbon contents, which should compensate for inefficient feeding on small prey.

The greatest amount of intraguild predation often is on species having very similar diets (Polis et al. 1989). The highest predation by Aequorea victoria was on 2 species with high dietary overlap (Phialidium gregarium, Rathkea octopunctata). Aglantha digitale and Proboscidactyla flavicirrata had the least dietary overlap with $A$. victoria, and they were the only 2 species for which feeding selection by $A$. victoria was significantly negative.

Competition for food could exist among zooplanktivores if food were limiting. Predation by soft-bodied zooplanktivores was 1 to $37 \% \mathrm{~d}^{-1}$ in Kulleet Bay. Similarly, in nearby Saanich Inlet, Larson (1985) found that at 0 to $5 \mathrm{~m}$ depth during April to June 1983, daily consumption of the mesozooplankton standing stock by gelatinous zooplankton increased from 1 to $17 \%$. Huntley \& Hobson (1978) found that predation due to a doubling of medusa biomass between June 12 and July 2,1975 , reduced zooplankton to a quarter of its biomass in Saanich Inlet. Therefore, there is evidence that high predation levels can exceed zooplankton production, and zooplankton stocks may be reduced, causing competition for food among the zooplanktivores in this environment.

Intraguild predators like Aequorea victoria feed high on the trophic pyramid and may have a surprising amount of control on the planktonic food chain (Baird \& 
Ulanowicz 1989). Those authors concluded that the intraguild predator Chrysaora quinquecirrha controlled crustacean zooplankton during the summer in Chesapeake Bay. I have shown that predation by $A$. victoria may affect densities of other gelatinous zooplanktivores that can affect zooplankton densities. Therefore, intraguild predation by $A$. victoria may release predation pressure on zooplankton populations. Predation can be very important in controlling plankton dynamics in the marine environment.

Acknowledgements. The research in Canada was possible thanks to the facilities and cooperation provided by $G$. O. Mackie and the Biology Department of the University of Victoria. It was supported by a North Atlantic Treaty Organization postdoctoral. fellowship to the author and a Natural Science and Engineering Research Council of Canada strategic grant to G. O. Mackie. I thank G. A. Polis and L. P. Madin for comments on an earlier version of the manuscript. UMCEES Contribution No. 2215

\section{LITERATURE CITED}

Baird, D., Ulanowicz, R. E. (1989). The seasonal dynamics of the Chesapeake Bay ecosystem. Ecol. Monogr 59: 329-364

Donaldson, S., Mackie, G. O., Roberts, A. (1980). Preliminary observations on escape swimming and giant neurons in Aglantha digitale (Hydromedusae: Trachylina). Can. J. Zool. 58: 549-552

Feigenbaum, D. Kelly, M. (1984). Changes in the lower Chesapeake Bay food chain in presence of the sea nettle Chrysaora quinquecirrha (Scyphomedusa). Mar Ecol. Prog. Ser 19: 39-47

Greve, W (1977). Interspecific interaction: the analysis of complex structures in carnivorous zooplankton populations. Helgoländer wiss. Meeresunters. 30: 83-91

Hodgkin, E., Rippingale, R. (1971). Interspecies conflict in estuarine copepods. Limnol. Oceanogr 16: 573-576

Huntley, M. E., Hobson, L. A. (1978). Medusa predation and plankton dynamics in a temperate fjord, British Columbia. Can. J. Fish. Res. Bd Can. 35: 257-261

Kohn, A. J., Riggs, A. C. (1982). Sample size dependence in measures of proportional similanty. Mar. Ecol. Prog. Ser. 9 $147-151$

This article was presented by D. K. Stoecker, Woods Hole, Massachusetts, USA
Larson, R. J. (1985). Trophic ecology of gelatinous predators (Cnidaria \& Ctenophora) in Saanich Inlet, Vancouver Is. B.C. Canada. Ph. D. thesis, Univ. of Victoria

Lenhoff, H. M. (1964). Reversible inhibition of swimming in Stomotoca atra by mesogleal extracts of some other medusae. Biol. Bull. mar biol Lab., Woods Hole 126: $115-120$

Pearre, S., Jr (1982a). Estimating prey preference by predators: uses of various indices, and a proposal of another based on $\chi^{2}$ Can. J. Fish. Aquat. Sci. 39: 914-923

Pearre, S., Jr (1982b). Feeding by Chaetognatha: aspects of inter-and intraspecific predation. Mar Ecol. Prog. Ser 7: $33-45$

Pennington, J. T (1990). Predation by hydromedusae on hydrozoan embryos and larvae: planktonic kin selection? Mar. Ecol. Prog. Ser 60: 247-252

Plotnikova, E. D. (1961). On the diets of medusae in the littoral of eastern Murman. In: Kamshilov, M. M. (ed.) Hydrological and biological features of the shore waters of Murman. Akad. Nauk. USSR Kolsk. Fil., p. 153-166

Polis, G. A., Myers, C. A., Holt, R. D. (1989). The ecology and evolution of intraguild predation: potential competitors that eat each other. Ann. Rev. Ecol. Syst. 20: 297-330

Purcell, J. E. (1982). Feeding and growth of the siphonophore Muggiaea atlantica (Cunningham 1893). J. exp. mar Biol. Ecol. 62: 39-54

Purcell, J. E. (1989). Predation on fish larvae and eggs by the hydromedusa Aequorea victoria at a herring spawning ground in British Columbia. Can. J. Fish. Aquat. Sci. 46: $1415-1427$

Purcell, J. E. (1990). Soft-bodied zooplankton predators and competitors of larval herring (Clupea harengus pallasi) at herring spawning grounds in British Columbia. Can. J. Fish. Aquat. Sci. 47: 505-515

Purcell, J. E. (1991). A review of cnidarians and ctenophores feeding on competitors in the plankton. Hydrobiologia/ Dev. Hydrobiol. (in press)

Purcell, J. E., Mills, C. E. (1988). The correlation between nematocyst types and diets in pelagic Hydrozoa. In: Hessinger, D. A., Lenhoff, H. M. (eds.) The biology of nematocysts. Academic Press, Inc., San Diego, p. 463-485

Spencer, A. N. (1975). Behavior and electrical activity in the hydrozoan Proboscidactyla flavicirrata (Brandt). II. The medusa. Biol. Bull. mar. biol. Lab., Woods Hole 149: $236-250$

Strand, S. W. Hamner, W. M. (1988). Predatory behavior of Phacellophora camischatica and size-selective predation upon Aurelia aurita (Scyphozoa: Cnidaria) in Saanich Inlet, British Columbia. Mar Biol. 99: 409-414.

Manuscript first received: March 28, 1990 Revised version accepted: March 14, 199 ! 